\title{
Photoassimilation of Fatty Acids, Fatty Alcohols and Sugars by Euglena gracilis $\mathbf{Z}$
}

\author{
By KEISUKE HOSOTANI, ${ }^{1}$ TAKATOSHI OHKOCHI, ${ }^{2} \dagger$ HIROSHI INUI, ${ }^{2} \ddagger$ \\ AKIHO YOKOTA, ${ }^{2 *}$ YOSHIHISA NAKANO ${ }^{2}$ AND \\ SHOZABURO KITAOKA ${ }^{2}$ \\ ${ }^{1}$ Faculty of Education, Wakayama University, Wakayama 640, Japan, \\ ${ }^{2}$ Department of Agricultural Chemistry, University of Osaka Prefecture, Sakai, Osaka 591, \\ Japan
}

(Received 26 March 1987; revised 20 July 1987)

\begin{abstract}
Assimilation of fatty acids, fatty alcohols and sugars by Euglena gracilis $\mathrm{Z}$ was investigated with or without illumination. Propionate, butyrate, valeriate, hexanoate, myristate, palmitate, ethanol, propanol, lauryl alcohol, tridecanol and myristyl alcohol supported considerable growth. The assimilation of propionate, valeriate, palmitate, butanol, lauryl alcohol and myristyl alcohol were strictly light-dependent. The photoassimilation of myristyl alcohol was saturated by lower light intensity than photosynthesis and was not completely inhibited by a photosynthetic inhibitor, suggesting involvement of a photoreaction other than photosynthesis in the photoassimilation. D-Glucose, D-fructose, D-galactose, D-xylose, D-glyceraldehyde and glycerol also supported growth. Disaccharides were not used as the carbon source for growth. The difference in the mechanism of photoassimilation between myristyl alcohol and D-galactose is discussed.
\end{abstract}

\section{INTRODUCTION}

Euglena gracilis utilizes sugars, amino acids, fatty acids, fatty alcohols and proteins as organic carbon sources (Cook, 1968; Barras \& Stone, 1968; Kempner, 1982). Growth of the organism on several amino acids is light dependent (Oda et al., 1982). Assimilation of propionate by $E$. gracilis also strictly depends on illumination, and the mechanism of the photoassimilation of propionate has been elucidated (Hosotani et al., 1980; Yokota et al., 1982). We have studied the growth of $E$. gracilis on fatty acids, fatty alcohols and sugars, and found that the organism also photoassimilates some of these carbon sources. It is of importance to compare the mechanisms of the photoassimilation of propionate and the other carbon sources. The present paper demonstrates the effect of light on the growth of $E$. gracilis on these carbon sources and compares the mechanisms of their photoassimilation.

\section{METHODS}

Organism and culture. Euglena gracilis $\mathrm{Z}$ and its streptomycin-bleached mutant (Oda et al., 1982) were used throughout. Stock cultures of the wild-type were grown photoautotrophically in air at $\mathrm{pH} 6.8$ in the medium of Cramer \& Myers (1952), which was also used as the basal medium for organic-carbon-assimilation experiments. The bleached mutant was maintained in the medium of Koren \& Hutner (1967). Both cultures (150 ml) were

† Present address: R \& D Laboratory, Fuji Oil Co., Ltd, Izumisano, Osaka 598, Japan.

$\ddagger$ Present address: Department of Food and Nutrition, Narabunka Women’s Junior College, Yamatotakada, Nara 635, Japan.

Abbreviation: DCMU, 3-(3,4-dichlorophenyl)-1,1-dimethylurea.

0001-4101 (C) 1988 SGM 


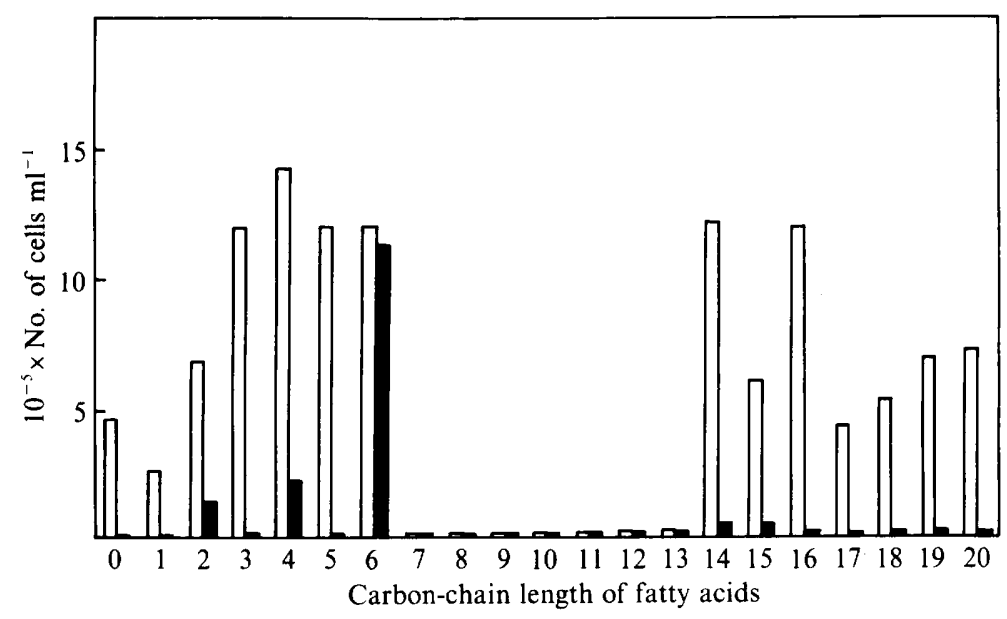

Fig. 1. Growth of E. gracilis on fatty acids with or without illumination. Photoautotrophically grown cells were transferred to culture media containing individual fatty acids and cultivated for $14 \mathrm{~d}$ with or without illumination. The initial cell number was $0.9 \times 10^{4} \mathrm{ml}^{-1}$. Open and closed bars represent growth of Euglena with and without illumination, respectively. A carbon-chain length of zero indicates photoautotrophic growth.

shaken reciprocally $\left(105\right.$ strokes $\left.\mathrm{min}^{-1}\right)$. The initial concentrations of sugars, sugar-related compounds, fatty acids and fatty alcohols were $1,0 \cdot 5,0 \cdot 2$, and $0 \cdot 2 \%(\mathrm{w} / \mathrm{v})$, respectively. The cell number in the culture was determined with a haemocytometer.

Determination of myristyl alcohol in the culture medium. E. gracilis cells were removed from cultures by centrifugation ( $4000 \mathrm{~g}$ for $5 \mathrm{~min}$ ). Myristyl alcohol in the medium was extracted into $50 \mathrm{ml}$ of chloroform. The chloroform layer was evaporated to dryness, redissolved in a small volume of chloroform, and the myristyl alcohol was determined by gas-liquid chromatography (Inui et al., 1983).

Extraction and determination of paramylon and wax esters. These were done as described previously (Inui et al., 1983, 1986; Yakota \& Kitaoka, 1982).

Feeding experiments with $\left[U_{-14}\right.$ C]galactose. A culture of $E$. gracilis cells grown on D-galactose for $7 \mathrm{~d}$ under illumination was divided into two parts. One part was grown for a further $7 \mathrm{~d}$ under illumination (light cells), and the other part was incubated in the dark for $7 \mathrm{~d}$ (dark cells). Both types of cells were collected by centrifugation at $2000 \mathrm{~g}$ for $3 \mathrm{~min}$ and suspended in $10 \mathrm{~mm}$-potassium phosphate buffer ( $\mathrm{pH} 6.8$ ). The procedures with the dark cells were done in the dark. Both types of cell were fed with $0 \cdot 1 \mu \mathrm{Ci}\left[\mathrm{U}-{ }^{14} \mathrm{C}\right] \mathrm{galactose}\left(0.01 \mu \mathrm{Ci} \mu \mathrm{mol}^{-1}, 370 \mathrm{~Bq} \mu \mathrm{mol}^{-1}\right)$ for 15 and $60 \mathrm{~min}$; the light cells were illuminated at $3000 \mathrm{~lx}$ while the dark cells were kept in the dark. Fractionation of cellular components and the trapping of evolved $\mathrm{CO}_{2}$ were done as reported by Yokota et al . (1978).

\section{RESULTS}

\section{Assimilation of fatty acids and fatty alcohols for growth}

Propionic, butyric, valeric, hexanoic, myristic and palmitic acids supported considerable growth of the E. gracilis cells under illumination; acetic acid and the acids $\mathrm{C}_{15}$ and $\mathrm{C}_{18}-\mathrm{C}_{20}$ gave less growth (Fig. 1). In the dark, only hexanoic acid gave similar growth as under illumination. The fatty acids $\mathrm{C}_{7}-\mathrm{C}_{13}$ did not allow growth in light or dark.

The pattern of growth of E. gracilis on homologous fatty alcohols (Fig. 2) was different from that on fatty acids. Ethanol was the best carbon source in both light and dark. Propanol, butanol, lauryl alcohol, tridecanol and myristyl alcohol also supported considerable growth under illumination. Assimilation of butanol, lauryl alcohol and myristyl alcohol for growth strictly depended on illumination. The fatty alcohols $\mathrm{C}_{5}-\mathrm{C}_{11}$ inhibited growth, and methanol and the alcohols $\mathrm{C}_{15}-\mathrm{C}_{20}$ did not support growth. 


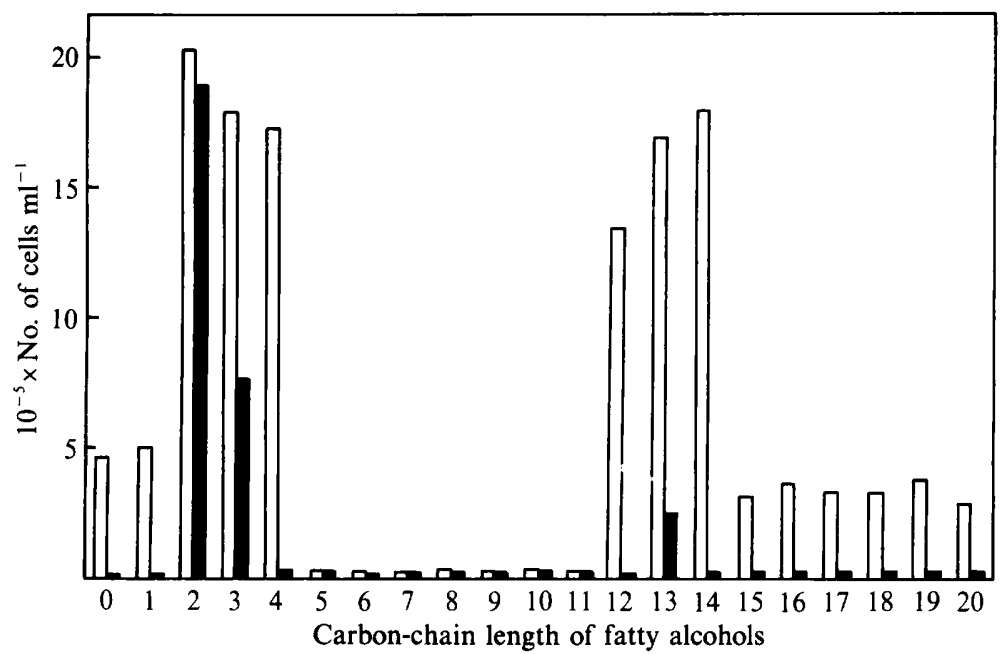

Fig. 2. Growth of E. gracilis on fatty alcohols. See the legend to Fig. 1 for details.

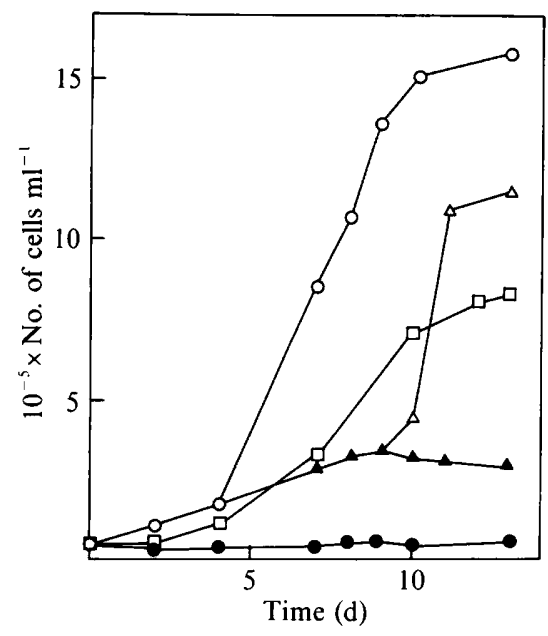

Fig. 3

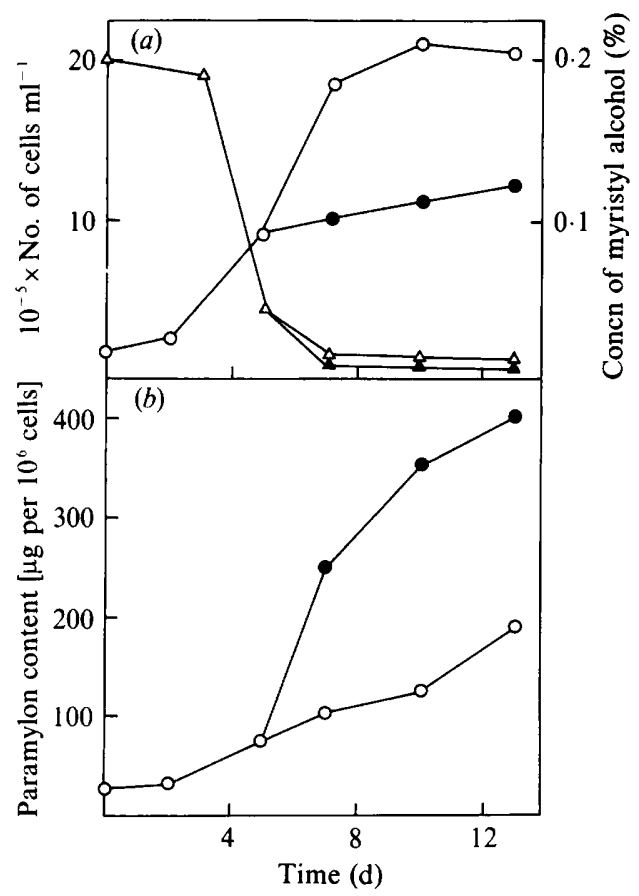

Fig. 4

Fig. 3. Effect of photosynthesis on the growth of E. gracilis on myristyl alcohol. E. gracilis was grown on myristyl alcohol under illumination (O), in the presence of $10^{-5} \mathrm{M}$-DCMU under illumination ( $\square$ ), or in the dark (O). A culture in the light was wrapped with dark cloths after $4 \mathrm{~d}$ illumination $(\Delta)$, and half of this culture was reilluminated from the 9 th day $(\triangle)$.

Fig. 4. Effect of illumination on the uptake of myristyl alcohol by E. gracilis (a) and concomitant change in intracellular content of paramylon $(b)$. Half of the culture of $E$. gracilis growing on myristyl alcohol was shaded at the 5 th day and kept in the dark. Growth of E. gracilis $(O, O)$ and concentration of myristyl alcohol in the growth medium $(\triangle, \mathbf{\Delta})$ in $(a)$ and intracellular content of paramylon $(O, O)$ in (b) were followed in the light (open symbols) and in the dark (filled symbols). 
Table 1. Distribution of radioactivity after incubation of the light and dark cells of E. gracilis with $\left[U-{ }^{14} \mathrm{C}\right]$ galactose with and without illumination, respectively

The light $\left(2.3 \times 10^{7} \mathrm{ml}^{-1}\right)$ and dark $\left(2.2 \times 10^{7} \mathrm{ml}^{-1}\right)$ cells were incubated as described in Methods. Values are expressed as a percentage of the total radioactivity taken up in each experiment.

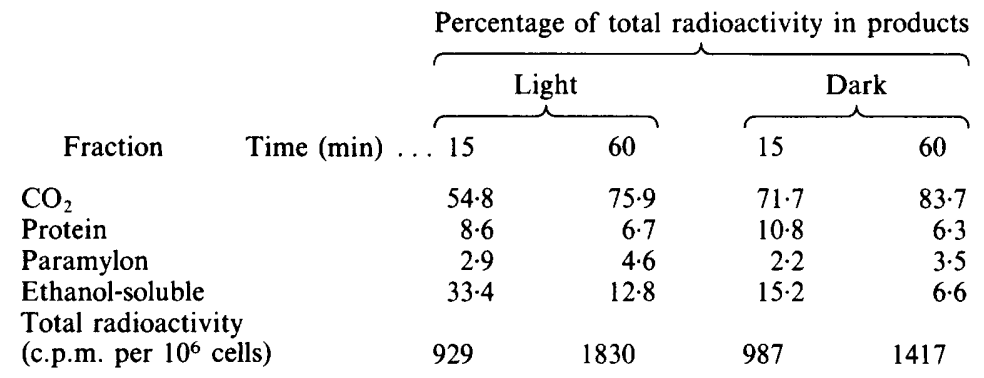

\section{Mechanism of photoassimilation of myristyl alcohol}

Although assimilation of myristyl alcohol by $E$. gracilis was strictly light-dependent as shown in Fig. 2, 3-(3,4-dichlorophenyl)-1,1-dimethylurea (DCMU), an inhibitor of photosynthetic electron transfer (Izawa, 1977), did not inhibit growth completely on this alcohol (Fig. 3). With the bleached mutant of $E$. gracilis, a long lag-phase extending to more than $10 \mathrm{~d}$ occurred before growth started under illumination, and the final cell yield was about half that observed with wild-type cells (data not shown). The rate of photoautotrophic growth of $E$. gracilis increased with increasing light intensities to at least $2000 \mathrm{~lx}$, but growth on myristyl alcohol was almost saturated by $600-1000 \mathrm{~lx}$ (data not shown).

There was a relationship between growth of E. gracilis on myristyl alcohol with and without illumination and the intracellular content of paramylon, the reserve polysaccharide of this organism (Fig. 4). As soon as the cells were shaded, growth stopped, but myristyl alcohol was taken up by the cells at a similar rate both with and without illumination. The paramylon content was increased up to twice as much as that of the control light cells by shading the cells. Wax esters were a minor cell component in the wild-type and mutant cells grown under the conditions described here.

\section{Assimilation of sugars and sugar-related compounds for growth}

D-Glucose and D-fructose were the best carbon sources, as reported previously (Barras \& Stone, 1968). D-Glyceraldehyde, D-galactose and glycerol were also carbon sources for growth although the cell yields were less than those with D-glucose and D-fructose. The following sugars and sugar-related compounds did not support growth: D-ribose, L-arabinose, D-mannose, D-sorbose, D-rhamnose, maltose, sucrose, trehalose, lactose, raffinose, starch, erythritol, D-sorbitol, D-galactitol, D-mannitol, inositol, D-glucuronic acid, D-gluconic acid, D-galacturonic acid, D-glucosamine hydrochloride and $N$-acetyl-D-glucosamine.

Assimilation of D-galactose and D-xylose by E. gracilis was affected by light. Growth of E. gracilis on D-galactose was strictly dependent on light although the sugar was taken up both in the light and in the dark at similar rates (Table 1). The addition of $50 \mu \mathrm{M}$-DCMU caused complete inhibition of growth, and the bleached mutant could not grow on D-galactose at all. In the dark, most of the radioactivity incorporated from $\left[\mathrm{U}^{-14} \mathrm{C}\right]$ galactose was recovered in the evolved $\mathrm{CO}_{2}$; the radioactivity in the evolved $\mathrm{CO}_{2}$ decreased under illumination, and incorporation into the ethanol-soluble (intermediate metabolite fraction) and paramylon fractions increased (Table 1).

\section{DISCUSSION}

E. gracilis grew on various fatty acids and alcohols as the sole carbon source. Assimilation of these carbon sources except for hexanoic acid and ethanol was largely affected by light. The 
reason why the dependence of growth on light varied from one compound to another is not clear. Methanol did not support growth and formate suppressed photoautotrophic growth in air although formate is taken up and metabolized in this organism (Cossins et al., 1979; Yokota et $a l ., 1985)$. The acids with chain lengths of 7-13 carbon atoms and the alcohols with chain lengths of 5-11 carbons inhibited the photoautotrophic growth of $E$. gracilis completely, and killed the cells. Other varieties of $E$. gracilis (E. gracilis Reinhardt, $E$. gracilis var. robusta, E. gracilis Klebs and $E$. gracilis var. urophora and the natural chloroplast-less mutant of $E$. gracilis, Astasia sp.) have been reported to grow on these middle carbon-chain-length fatty acids and alcohols (Barras \& Stone, 1968), although these compounds are well-known antifungal agents.

The mechanism of photoassimilation of myristyl alcohol is different from that of propionate, assimilation of which strictly depends on ATP produced in photosynthesis (Hosotani et al., 1980; Yokota et al., 1982). E. gracilis grew on myristyl alcohol even in the presence of DCMU, which indicates that photosynthetic energy is not completely necessary for the photoassimilation of myristyl alcohol. This view is further supported by the data presented in this paper showing that the growth of the chloroplast-less bleached mutant on myristyl alcohol was also light-dependent and the photoassimilation of the alcohol in the wild-type cells was saturated at a lower light intensity than that for photosynthesis. The synthesis of L-ascorbate by wild-type cells and by the bleached mutant of $E$. gracilis (Shigeoka et al., 1979), and glycolate dehydrogenase production in the bleached mutant (Yokota \& Kitaoka, 1981), are induced by dim light of wavelength around $420 \mathrm{~nm}$. The blue light receptor may take part in the photoassimilation of myristyl alcohol. In addition to this light reaction, photosynthesis also appears to have some relation to the photoassimilation since the occurrence of photosynthesis during the culturing caused a higher final cell yield (Fig. 1).

The paramylon content of the Euglena cells was increased up to $400 \mu \mathrm{g}$ per $10^{6}$ cells by shading (Fig. 4). The accumulation of paramylon is apparently due to a metabolic change caused by the shading. Generally, blue light stimulates synthesis of amino acids from sugars in photosynthetic micro-organisms (Voskresenskaya, 1979). Shading of E. gracilis growing on myristyl alcohol may have caused the accumulation of paramylon and lowered synthesis of amino acids and protein which are essential for the cell growth. In this context, we should note that the bleached mutant adapts to the myristyl alcohol medium after several transfers (Inui et al., 1986) although addition of high concentrations of $\left(\mathrm{NH}_{4}\right)_{2} \mathrm{SO}_{4}$ to the culture medium was essential for the adaptation (unpublished). The mutant might induce the ability to synthesize amino acids from myristyl alcohol by the adaptation.

D-Glucose and D-fructose were the best carbon sources for growth of $E$. gracilis. Disaccharides such as sucrose were not assimilated at all, although sucrose was used for the cultivation of E. gracilis (Hulanicka et al., 1964). Since sucrose was completely hydrolysed to D-glucose and D-fructose during autoclaving at $120^{\circ} \mathrm{C}$ and $\mathrm{pH} 3.5$ for 20 min (unpublished), the apparent utilization of the disaccharide should be ascribed to its hydrolysis products formed during preparation of the growth medium.

E. gracilis apparently photoassimilated D-galactose and D-xylose. Growth on these sugars was completely inhibited by DCMU under illumination, and the bleached mutant could not utilize the sugars for growth. In spite of that, both sugars were taken up by the cells with and without illumination. In the case of D-galactose, most of the carbon atoms were converted to $\mathrm{CO}_{2}$ in the dark, and the evolution of $\mathrm{CO}_{2}$ was decreased under illumination. This suggests a mechanism different from that of the photoassimilation of myristyl alcohol in that the $\mathrm{CO}_{2}$ originated from D-galactose through oxidation by the cells was re-fixed by photosynthesis and re-fixed $\mathrm{CO}_{2}$ supported growth.

\section{REFERENCES}

Barras, D. R. \& Stone, B. A. (1969). Carbohydrate composition and metabolism in Euglena. In The Biology of Euglena, vol. 2, pp. 149-191. Edited by D. E. Buetow. New York: Academic Press.
Cook, J. R. (1968). The cultivation and growth of Euglena. In The Biology of Euglena, vol. 1, pp. 243314. Edited by D. E. Buetow. New York: Academic Press. 
Cossins, E. A., Foo, S. S. K. \& LoR, K. L. (1979) Generation of one-carbon units in methioninesupplemented Euglena cells. Phytochemistry 18, 1967-1971.

Cramer, M. \& Myers, J. (1952). Growth and photosynthetic characteristics of Euglena gracilis. Archiv für Mikrobiologie 17, 384-402.

Hosotani, K., YoKota, A., NaKano, Y. \& Kitaoka, S. (1980). The metabolic pathway of propionate in Euglena gracilis $\mathrm{Z}$ under illumination. Agricultural and Biological Chemistry 44, 1097-1103.

Hulanicka, D., ERwin, J. \& Bloch, K. (1964). Lipid metabolism of Euglena gracilis. Journal of Biological Chemistry 239, 2778-2787.

Inui, H., Miyatake, K., Nakano, Y. \& Kitaoka, S (1983). Production and composition of wax esters by fermentation of Euglena gracilis. Agricultural and Biological Chemistry 47, 2669-2671.

Inui, H., Ohya, O., Miyatake, K., Nakano, Y. \& KITAOKA, S. (1986). Assimilation and metabolism of fatty alcohols in Euglena gracilis. Biochimica et biophysica acta 875, 543-548.

IZAWA, S. (1977). Inhibitors of electron transport. In Encyclopedia of Plant Physiology, vol. 5, pp. 266-282. Edited by A. Trebst \& M. Avron. Berlin: Springer.

KEMPNER, E. S. (1982). Stimulation and inhibition of the metabolism and growth of Euglena gracilis. In The Biology of Euglena, vol. 3, pp. 197-252. Edited by D. E. Buetow. New York: Academic Press.

Koren, L. E. \& HUTNER, S. H. High-yield media for photosynthesizing Euglena gracilis Z. Journal of Protozoology 14 (Supplement), 17.
Oda, Y., Nakano, Y. \& Kitaoka, S. (1982). Utilization and toxicity of amino acids in Euglena gracilis. Journal of General Microbiology 128, 853-858.

ShigeOKa, S., Yokota, A., NaKano, Y. \& Kitaoka, S. (1979). The effect of illumination on the L-ascorbic acid content in Euglena gracilis Z. Agricultural and Biological Chemistry 43, 2053-2058.

VOSKRESENSKAYA, N. P. (1979). Effect of light quality on carbon metabolism. In Encyclopedia of Plant Physiology, vol. 6, pp. 174-180. Edited by M. Gibbs \& E. Latzko. Berlin: Springer.

YoKoTA, A. \& KitAOKA, S. (1981). Occurrence and subcellular distribution of enzymes involved in the glycolate pathway and their physiological function in a bleached mutant of Euglena gracilis Z. Agricultural and Biological Chemistry 45, 15-22.

Yokota, A. \& Kitaoka, S. (1982). Synthesis, excretion, and metabolism of glycolate under highly photorespiratory conditions in Euglena gracilis $\mathbf{Z}$. Plant Physiology 70, 760-764.

Yokota, A., NaKano, Y. \& Kitaoka, S. (1978). Metabolism of glycolate in mitochondria of Euglena gracilis. Agricultural and Biological Chemistry 42, 121-129.

Yoxota, A., Hosotani, K. \& Kitaoka, S. (1982). Mechanism of metabolic regulation in photoassimilation of propionate in Euglena gracilis Z. Archives of Biochemistry and Biophysics 213, 530-537.

Yokota, A., Komura, H. \& Kitaoka, S. (1985). Different metabolic fate of two carbons of glycolate in its conversion to serine in Euglena gracilis Z. Archives of Biochemistry and Biophysics 242, 498-506. 